\title{
Fractured Resistance: Queer Negotiations of the Postcolonial in R. Raj Rao's The Boyfriend
}

\author{
Sandeep Bakshi \\ University of Leicester, UK
}

[Abstract: This essay assesses South Asian queer identity as it relates to the state of postcolonialism. It pays particular attention to the ways in which queerness engages with fractures of the heteropatriarchal nation. Focusing on R. Raj Rao's novel The Boyfriend (2003), I work contrary to the logic of romantic idealization that would position the postcolonial nation against repressive homophobic statutes of colonialism. My reading suggests that the postcolonial nation is complicit with the former colonial project in marginalizing and policing queerness.]

$\mathrm{O}$ n July 2, 2009, the Delhi High Court delivered a judgment in favor of the Naz Foundation, an organization that works for same-sex equality, declaring that the application of Section 377 of the Indian Penal Code that penalized consensual sex among adults was unconstitutional. The decriminalization of homosexuality enacted by the landmark decision rescinded in part-it retained non-consensual sex as criminal - the colonial penalization of same-sex practices introduced by T.B. Macaulay in 1860 that prohibited "carnal intercourse against the order of nature with any man, woman or animal" (qtd. in Narrain and Elridge 9). Heralded as a "great victory over an archaic and bizarre law," the successful culmination of a decade-long political mobilization created a distinct temporal divide between pre- and post-2009 queer activism in India ("Gay Ruling").

South Asian Review, Vol. 33, No. 2, 2012 
Reviewing the complexity of colonial/postcolonial legal frames, Kajal Bhardwaj considered the verdict as an exemplar of "the ultimate vision of India - a society based on inclusiveness" (99). The announcement, without a doubt, signals a step further in the process of decolonization from inherited homophobic laws in postcolonial India. However, the ruling only "read down" the statute and, as queer militant Gautam Bhan states, it did not "challenge the very idea that the state, law and society has the right to decide that certain acts are "unnatural" (45). Faulting the euphoric celebration therefore, Ashley Tellis, a samesex rights activist from Delhi, decries the alignment of the queer movement in India with "international human rights speak" at the expense of intersectional politics and "analogous reasoning with various other minorities like Dalits, adivasis [tribes] and religious minorities" ("Why I Can't Join the Party"). His timely response to the almost homonationalist deployment of the sentence, in terms of "the ultimate vision of India," contextualizes the specific fissures of postindependent/postcolonial India and, in more crucial ways, underlines the immediacy of developing coalitional politics of solidarity between the various embattled groups that include women, Muslims, Dalits and sexual and gender minorities. ${ }^{1}$ Given the disparate socioeconomic, linguistic and religious privileges/non-privileges of identitarian clusters in contemporary India, I would claim that the "great victory" against homophobia remains partial. In this regard, prior to or post-2009, opposition to the prevalent homophobic discourse, national or cultural, constitutes what I term "fractured resistance" when it does not adequately address the problematic severances based upon class, caste, gender and sexuality within the postcolonial nation.

This essay builds upon the above-mentioned discussion about Indian queer identity as it relates to the state of postcolonial India. Focusing on R. Raj Rao's first novel The Boyfriend (2003), it examines the intractability of questions pertaining to same-sex desire from debates apropos national culture. ${ }^{2}$ The novel relates the homoromance of Yudi, an upper-class journalist in his forties and his nineteen-yearold Dalit (untouchable) boy-lover, Milind Mahadik, an office boy. When he is hired by a modeling/call-boy agency, Milind disappears from Yudi's life. Distraught at the loss of his boyfriend, Yudi spends most of his time with Gauri, a female friend and an upcoming painter who is in love with him. Milind, however, returns to his parents' home, where he discovers that the family has arranged his marriage with a girl of their choice. Milind agrees to this heterosexual union since he had never thought of himself as being part of the gay subculture. Nevertheless, after marriage, Milind realizes that his deteriorating financial means cannot suffice for his family and, at the advice of his wife, calls upon Yudi for a sexual encounter. Eventually, Milind's visit 
evolves into a routine affair in return for monetary favors. The novel captures a distinct Indian context of queerness where interconnections of class, caste, language, religion, gender and sexuality figure within a matrix of the state of the postcolonial nation. It explores the intersection of dominant discourses of the nation and (hetero)sexuality and critiques them both by showing the (im-)possibility of cross-caste and same-sex love.

Written just a few years after the turn of the Millennium in 2003, the novel links to a larger frame of queer fiction in English that has recently begun to emanate from South Asia and its diasporas. The articulation of non-normative desire becomes central in the growing canon of South Asian queer fiction, which includes Suniti Namjoshi's creative account The Conversations of Cow (1985), Hanif Kureishi's premier narrative of The Buddha of Suburbia (1990), Shyam Selvadurai's first text Funny Boy (1997), P. Parivaraj's sole work Shiva and Arun (1998) and Manju Kapur's novel A Married Woman (2003). The Boyfriend therefore becomes crucial in the manifold ways in which it steers postcolonial fiction toward newer routes that include representation of queerness as central to the significant theme of fractures within the nation.

Set in Bombay (Mumbai) in the early 1990s, Rao's work intervenes as a queer narrative of resistance to heteronormative and nationalist impulses in India. Although Parmesh Shahani celebrates it as the first work of fiction "to be fully pivoted around homosexuality" from India, I work contrary to the logic of romantic idealization that would position the postcolonial nation against repressive homophobic statutes of colonialism (197). Instead, by exposing the critical fissures of post-independent India in terms of multiple binary divisions, I highlight the impossibility of a union based on same-sex and crosscaste love that emerges from the novel. My reading suggests that the postcolonial nation is complicit with the former colonial project in marginalizing and policing queerness. The national and, more significantly, the nationalist frameworks of postcolonial India prolong the colonial production of normative gender and sexuality. In such a structural duplication of the social norm, reproductive heterosexuality attains legitimacy as the unique, "natural" choice of the postcolonial nation.

My reading contends that Rao's text attempts to negotiate a site of alternative sexualities when, as Mary E. John and Janaki Nair suggest, the theorizing of sexuality itself in the Indian context is relatively new, given the "conspiracy of silence regarding sexuality in India" (1). I argue that the novel is about the state of the (post)colonial nation as much as about (homo)sexuality, since both are inextricably linked to one another in the novel. It exposes, as Jyoti Puri would aver, "the 
[parallel] role of the post-colonial nation-state in producing and reproducing hegemonic codes of sexuality and gender" (174). Exploring the inflections of class, language and privilege, and caste in the Indian context as they unfold in the wider framework of sexuality, it also reclaims Hindu myths from a queer perspective. Therefore, I look at how representation of homosexuality refigures India through a rereading of cultural myths which form a part of (Hindu) national(ist) identity. The significance of the novel lies in the crossing of homosexual love with the state of the postcolonial nation, thus pointing to the elision of a queer perspective in postcolonial studies.

In The Boyfriend, the citation of national history becomes the symbolic context of the homosexual relationship. The love plot of Yudi and Milind, who are both Hindus, is charted against the backdrop of the Hindu-Muslim Bombay riots of 1992 . The riots were a point of culmination of the deteriorating community relations between Hindus and Muslims in free India. The Babri Masjid (mosque) in the city of Ayodhya (Uttar Pradesh) is a contentious site as both Hindus and Muslims refer to it as their holy site. The Hindu nationalists claim that it is the birthplace of God Rama and that the seventeenth-century mosque desecrates it. On December $6^{\text {th }}, 1992$, activists from fundamentalist Hindu organizations marched into Ayodhya and demolished the mosque, which in turn led to the worst Hindu-Muslim riots in the history of independent India, barring the Partition unrest in 1947. As a strategy of denouncing an increasing development of "Hindutva" (the idea of cultural and religious superiority of Hindus over other religions), post-1992 Indian novelists have often used the riots as emblematic of the destructive divisions in postcolonial India. Representations of homosexuality in recent Indian literature therefore document this anxiety surrounding Hindu-Muslim relations. For instance, Ruth Vanita asserts that, "gender-based anxieties are deeply intertwined with anxieties around religious, community and national identities," because of the "simultaneous and contradictory myths that Muslims introduced homosexuality into India or repressed its expression" (Queering India 8). Islam can therefore function both as a threat to queer sexuality and as an affirmative signifier of queerness. For instance, in Manju Kapoor's novel A Married Woman, Astha and her lover visit the site of the destroyed Babri Masjid in order to comprehend their lesbian relationship (56).

I contend that in Rao's novel, homosexuality and contemporary national history intersect within the discourse on desire so that the anxiety of the Hindu-Muslim divide reflects the equally disruptive potential of homosexual love to rewrite dominant discourses of a heteronormative nation. Not hearing from Milind after their initial meeting, Yudi wonders whether the boy has not been killed during the 
riots, as he inhabits those spaces (of poverty), which are the most vulnerable to public violence in riots. The social restlessness of the political events in 1992-93 mirrors the upheavals of love between Yudi and Milind. In his search for the boy, he traverses the areas hard hit by the riots (Rao 40-41). He even imagines that Kishore/Milind (Kishore is the pseudonym Milind gives Yudi on their first meeting), had been a victim of the riots, so that "life had fluttered into his hands, and then slipped away forever" (42). While Yudi only watches the riots as a witness, Milind later informs Yudi that he was actually a victim of the violence, for when he was going to work in his factory he nearly lost his life, as he inadvertently became a part of the Muslim group being chased by the Hindus (78-79).

The notion of interpreting homosexuality as a threat to the nation is a strategy devised by all nationalist discourses in order to contain likely disconcerting (homo)sexualities. As Puri explains, "national interests and the functions of the state can relate to the most intricate and explicit details of people's sexual lives" (145). The riots reveal the statenation's strategies to contain and police homosexuality. They ignite a more aggressive social atmosphere whereby the police use the rhetoric of national security to vent their anger and frustration on homosexuals. Remembering his days at the cruising areas of the Azad Maidan Park in Bombay in the 1980s, Yudi can only sigh that the ground lost its "former glory" in the 1990s due to the riots (48). As he remarks, "the post-Babri riots made the police vigilant. There were reports of gays being thrashed and thrown into the lock-up when they were found loitering in the Maidan after sunset" (49).

The imbrication of national(-ist) discourses and sexual sites constitutes the principal narrative thread of the novel. The interconnection between the nationalist and sexual formations appears at various critical junctures in The Boyfriend. For instance, Yudi casts his love for Milind and the difference in their ages in terms of national identity and its hyperbolic fictions. He asserts that if someone called him a "cradle snatcher," due to the difference in the ages of the two lovers, he would reply that "the boundary-line between filial and conjugal love is as imaginary as that between India and Pakistan" (40). In framing such an argument, Yudi critiques the biased "imaginary" construct of the nation and dominant discourses of sexuality whereby the object of sexual desire can only be an individual of the opposite sex and of the same age.

Moreover, Hindu nationalist fictions of a homogenized Hindu religion without any distinction of caste or class, which forms the basis for a "Hindu" India, are exposed when Milind informs Yudi that at the age of thirteen, the hardline Hindu party, the RSS had enrolled him, knowing well that he was not a Brahmin but a Dalit (79). The Rashtriya 
Swayamsevak Sangh (RSS, the National Organization of Self-Helpers) and its offshoot, the Vishwa Hindu Parishad (VHP, World Hindu Society), have gained increased visibility after the Bombay riots. They train numerous Hindus in guerrilla warfare in case of an eventual attack from the Muslims. It is of utmost importance to the workers of the RSS to project a hyper-masculine image of its recruits, partly because they wish to refute the colonial representation of "Hindu" India as an effeminate nation. Hema Chari asserts that in postcolonial India the fundamentalist national reaction, like the colonialist construction of India, demonstrates "an intense male anxiety about the integrity of male bodies, masculinity, and the nation state" (292). I suggest that the novel presents the counter-response to this nationalist reaction as homophobia. ${ }^{3}$ The RSS enrolls Milind despite prevalent caste divisions in Hinduism. His response to the hyperbolic construction of masculinity, evident in the RSS drills he performs, is steeped in homophobic insult. He considers the workers of the RSS as gandusthat is, men who are "penetrated" (79).

Yudi shares a complex relationship with the nation that is most apparent in his subject position as an upper-class, urban-educated, homosexual Indian. His attitude to the nation is one of disavowal and it arises from a complex amalgamation of his socially privileged status and his choice of partners from the lower ranks of society. The rejection of the lower classes and his paradoxical attraction to them becomes for Yudi a rejection of the postcolonial nation, which hinders a union between different classes. The sexual stereotypes of his partners constitute the sexual imaginary of all Indians for Yudi. Thus, "Indians will never stop being obsessed by size," even though Yudi himself is "disappointed" by the member of one of his partners (5-7). Milind's surname in the novel is Mahadik (Maha in Hindi means big or gigantic) and Yudi is quick to notice the ironical implication as Milind has a small member (8). His relationship with Milind develops along the binary of economic privilege and its lack. The novel condemns Yudi's attitude to consider the lower classes as a symbol for the entire nation by presenting Yudi as distanced, culturally and economically, from those deprived sections of society to which he feels attracted.

For Yudi, the lies of the gay subculture in India represent the lie of the nation-state. For his first encounter with Kishore/Milind, Yudi blindfolds him to take him to his mother's place, so that the boy would not blackmail him later, and yet when Yudi loses track of Kishore/Milind, he disowns the nation once again, as "Lies were what thieves spoke; gay love in India thrived on lies" (38). The reference to India in the above sentence must be read as a frustration at and a condemnation of the Indian state, which regards heterosexual marriage as the only platform for sexuality, thus coercing homosexual liaisons 
into lies and doubleness. The lies of the gay subculture (in India) become the lie of the nation-state. At the end of the novel, when Milind gets married and years pass without the lovers seeing each other, Bombay, the symbolic image of British India (and referred to as "Bombay" throughout the novel) is disavowed as Yudi settles for a more decolonized appellation of the city and resumes "his single-gayman-in-Mumbai routine" (221). The shift from Bombay to Mumbai in the novel signals the transition from the colonial to a postcolonial nation. However, if Bombay stands as a metaphor for colonial authority that introduced the 1860 edict of the criminalization of homosexuality and "unnatural acts," then the postcolonial self-representation symbolized in Mumbai is equally as oppressive and unsatisfactory for liminal identities as its former counterpart.

Certainly, Yudi's disavowal of the nation is a reaction against, and symptomatic of, the unease in recent debates about homosexuality, in particular, and sexuality, in general, in India. Hindu fundamentalists have routinely sought to redefine Indian national identity through the establishment of authorized and non-authorized versions of Indian sexuality. Vanita and Kidwai's attempt to recover same-sex narratives in Indian history in their anthology Same Sex Love in India (2000) defines a rich queer cultural heritage that can be made available to lesbians and gays in India. Certain queer scholars of India, however, address the question of homosexuality in ancient India in terms that are largely similar to nationalist discourses of sexuality. Such readings, as Puri suggests, "are confounded by the discourses of national cultural identity" (174). The reluctance of the nation-state to address the problematic issue of alternative sexualities is reflective of the cultural importance it attaches to marriage and, by extension, reproduction. The regulation of sexuality and gender in India reaches its point of culmination in the institution of (heterosexual) marriage, the privileged site for the nation-state to control and legitimize sexualities of individuals. Therefore, Yudi's reaction to the spectacle of Milind's marriage exposes the heteronormative apparatus of the nation: "In India marriage is like ablution, like washing one's arse. People marry involuntarily, just as they bring their left hand to their arse after a crap. Ditto with babies" (221). As the postcolonial nation represents Indianness by privileging heterosexuality through marriage and reproduction (and proscribing other forms of alternative sexualities), the novel illustrates that the nation has to be disavowed in order for it to be possible to embrace homosexuality, as in Yudi's case.

Marriage is a critical site for comprehending the nation's regulation of sexual and gender identities. Arvind Narrain argues that "in the laws that define marriage, divorce and adoption . . . the absent figure is the queer person" (62). Also, in her seminal work on same-sex 
marriage in India and the West, Vanita highlights the differences between religious or community marriages and institutional marriages. She explains that although in modern democracies the state controls and regulates marriages in the form of marriage registration, many variations of unions still exist, especially in India where many marriages are unregistered. Marriage is the outcome of reciprocal love or a mutual agreement, and often occupies a "private" space, even though several countries opt for institutional approval. Vanita affirms that "the Indian government recognizes as legal any marriage performed according to customary rites, whether or not a licence has been obtained" and that "this is a crucial difference between marriage law in modern India and most Western democracies"(Love's Rite 68, 72). Milind's heterosexual marriage is certainly one such marriage in which the religious ceremony legitimates the union. Nevertheless, if religious ceremonies can take precedence over state institutions, then Milind is already a married man. Milind and Yudi spend a week together in Yudi's flat in the symbolically named "Mate House" (96114). During their sojourn, they decide to consolidate their union by performing a Hindu marriage in which the groom (Milind) and the bride (Yudi, dressed up in his mother's sari) take seven rounds of the sacred fire to seal their marriage (107-08). Milind puts sindoor (red vermilion powder) in Yudi's parted hair, they walk around the sacred fire seven times as in Hindu marriages and they repeatedly exchange marriage vows: "I promise to be your humsafar (life partner), trust me, till death do us apart" (107). As proof of their marriage, they take photographs of the ceremony. Vanita has shown that in many Indian marriages, photographs of the ceremony can suffice to secure registration of a marriage (Love's Rite 37). In terms of institutional registration, a photograph of the ceremony often constitutes evidence of marriage. Thus, rather than becoming a mockery or an imitation of marriage, Milind and Yudi's queer wedding problematizes the relations of social and civil marriage if read in conjunction with Milind's heterosexual marriage later in the novel. Drawing upon the idea of a traditional bond as presented in ancient Hindu treatises, where no reference to the gender of the partners is mentioned, it likewise exposes the contradictions of the institution itself. Their queer union therefore reads as a critique of the modern state's regulatory regime that outlaws homosexuality.

Following Judith Butler and Homi Bhabha's analysis of the fraught relationship between imitation and the alleged original, the same-sex union in the novel highlights the fictional status of what constitutes legal marriage. Butler asserts that if heterosexuality is seen as "an impossible imitation," which has to repeat its "norms" of heterosexualized genders to pass as an original, then any parody of 
heterosexuality within homosexual cultures "is always and only an imitation of an imitation, a copy of a copy, for which there is no original"("Imitation" 313-14). The original heterosexual marriage read in light of the parodic imitation of Milind and Yudi's marriage appears thus to be a sham, an imitation and a copy. Likewise, Bhabha's concept of mimicry, through which he reads the ambivalence of colonial discourse, illuminates the national(ist) regulation of marriage. The colonized "mimic man," Bhabha argues, is only a "partial, incomplete Englishman" because the "colonial can only be (re-)produced partially," otherwise it loses its status as the dominant (87). Similarly, the national cannot be naturalized because the partial "representation rearticulates the whole notion of identity and alienates it from essence" (87). Seeking customary and ritual legitimization of their marriage through the ceremony performed at Yudi's flat, Yudi and Milind "perform" a parody of national identity in India, of which marriage is an important component. This parody denaturalizes the institution of marriage by alienating it from its "essence," which is heterosexual marriage and reproduction. Yudi and Milind's queer union therefore defeats the nation's attempt to naturalize itself through compulsory heteronormative marriage.

Rao's subversion of national identity transects with queer paradigms in meaningful ways in terms of Hinduism. The Hindu myth of Lord Krishna and his poor friend Sudama runs throughout the novel, as it reflects the differences between Yudi's and Milind's class and caste status. In the myth, Krishna visits Sudama's house where Sudama's poor wife has only one grain of rice to offer the guest. Krishna accepts the offering and even washes Sudama's feet as a part of accepting Sudama as his dear friend. In the novel, Milind's and Yudi's relationship often recalls the myth. At their first meeting at a bar called Testosterone, Yudi draws a parallel between their relationship and that of the homoerotic charge of the friendship between two mystics, Ramakrishna and Vivekananda, such that Milind is shocked at his comparison to Vivekananda since he is a Dalit. ${ }^{4}$ Rao's narrative challenges the rigid distinctions of class and caste by comparing Milind, a Dalit, to a respected mystic sage like Vivekananda. At the same meeting, Yudi compares them to Krishna and Sudama, telling Milind, "you are my Sudama and I will happily bathe your tired and grimy feet . . . right here with this beer!" (73). The Krishna-Sudama myth is traditionally regarded as a framework for appreciating crosscaste, cross-class friendships in Hindu culture.

Later, when Yudi pays his cousin a visit in the famous Taj hotel, he wants to smuggle sandwiches for Milind who is waiting in the lobby, for, he wonders, "when, otherwise, would his poor Sudama get to savour Taj food?"(97). Even Milind's wife Leela, on seeing the 
television serial Krishna, has the idea of sending her husband as a Sudama to Yudi's (Krishna's) house to ask for help in order to resolve their financial troubles (222). In a reworking of the myth, it is Milind/Sudama and not Yudi/Krishna who goes to his friend's home. Arriving tired at Yudi's place, Milind is made to sit down while Yudi rushes back "with a half-bucket of water and a mug . . . to wash the boy's feet," as Gauri watches this spectacle with a note of jealousy (227). Rao uses the myth to queer Hindu culture. For instance, the sexual charge of washing Milind's feet is a part of Yudi's sexual imaginary and expressions of love for the boy, as when he wanted to wash Milind's feet with beer in Testosterone. Rao uses the Krishna/Sudama myth in a creative way to destabilize the sole claim of nationalist discourses to India's cultural heritage. By reclaiming it from a queer perspective, he undermines a singular claim to it by the nationalists and in the process shows the tendency of nationalist discourses to read history and myths monolithically. The creative use of the myth in the novel gains force precisely because it is queered.

Apart from the revision of cultural myths, Rao mobilizes several other elements of resistance to heterosexist and nationalist narratives. The hijras (transgender and other non-cisgendered subjects), whose identities have often been erased by master narratives of the nation, are represented as an integral part of the queer subculture in Bombay. ${ }^{5}$ Thus, Shuklaji Street in Bombay represents the neighborhood of famous hijra sex workers (88). Similarly, when Milind joins the A.K. modeling agency, he finds that the callboys are classed into three categories and made to sleep in their respective dorms. Besides the usual active-passive role classification of the boys, the third dorm accommodates the "hijras, hermaphrodites, and high society blokes who'd had a sex change operation" (184).

Moreover, in response to the Indian state's official insistence on the absence of homosexuality in Indian culture and tradition, the novel highlights that the gay male subculture in Bombay has a highly developed though encoded linguistic framework. The Chhakke log (homosexuals) as the policeman Dyaneshwar puts it, includes two selfidentified drag queens Anarkali and Umrao Jaan (names of two famous Mughal courtesans), Gulab (rose) and her gang Raat Rani (queen of the night), Pinky, Sweety, Badnaseeb (the unfortunate one), Akash (the sky), Hira (diamond), Moti (pearl), Chandni (moonlight), Laila, Salma and Salma-ka-Balma (Salma's lover) (35). I would claim that Rao's narrative presents the use of an enscripted language for expressing a marginal sexuality as similar to that used by the hijra community in India. As Kira Hall suggests, by "mapping their own sexual ambiguity onto linguistic ambiguity India's hijras are able to locate themselves in an otherwise inaccessible social grid" (432). In his interactions with the 
queer subculture Yudi obviously knows the "slang of working class homos" such that dhakka start (a car that starts only when you push it) denotes a passive gay, and biryani khayega (literally, "would you like to have biryani") stands for rimming (30). Although several dominant discourses utilize euphemism as a quotidian practice, the complex linguistic frame of the queer community in Bombay serves the need for encoding language and, in so doing, becomes a political strategy to survive erasure from normative/nationalist discourses.

Furthermore, The Boyfriend interrogates received understandings of cisgender and gender identity through Yudi and Milind's relationship. Fluidity and multiple gender identifications are central to queer scholarship. Butler's anti-foundationalist analysis has helped queer studies to deconstruct normalizing discourses, which regard gender, sex and sexuality as mutually dependent and fixed categories. She claims that gender is a "corporeal style, an 'act,' as it were, which is both intentional and performative, where 'performative' suggests a dramatic and contingent construction of meaning" (Gender Trouble 177). Gender identity in the Butlerian sense is an effect of the acts of gender itself and is forever shifting since it is both "intentional and performative." Although Yudi gladly offers his partners "the active role in bed," his actions are governed by considerations of class rather than sexual preference (as he believes that the act of penetration, for many lower-class boys, does not amount to homosexual activity) (12). His relationship with Milind evolves through a variety of gender roles in which the line between masculine and feminine acts is constantly confounded (12). Milind makes it clear to Yudi at the beginning of their affair that he would not "take [it] in the mouth" or "take it in the arse" (82). However, the novel defies any neat or stable categorization of sexual and gender identities. During the preparation for their queer wedding, both vie for the place of the groom. Milind would like to be the groom because he feels that he has the "active" role in bed, while Yudi cites his being "the breadwinner" as an argument in his favor (107). Ultimately, Yudi becomes the bride; however, Milind decorates the house with rangoli, a customary decoration with colorful lines drawn across the landing as a sign of the presence of the new couple. Rangoli is habitually drawn by women in South India; this prompts Yudi to term Milind "his tender gender bender" (107-08). The episode primarily positions the novel in explicit opposition to the notion of gender as a binary construction and simultaneously proposes a critique of the stereotypical assumption that same-sex couples copy the heterosexualized norm of "man" and "woman."

Similarly, when Yudi gets into a brawl with a man eyeing Milind at Testosterone, the idea of being protected appeals to Milind, even though he does not wish a parallel identification with the feminine. In a 
confusion of gender and sexual identity, he wonders to himself: "He was no woman to be fought over. He was the one who fucked, wasn't he? And yet, he felt elated. Seeing Yudi's bloody face, he realized that there was someone at last who cared for him" (95). Although Milind's position vis à vis women, as shown later towards his wife, remains (hetero/homo)patriarchal and he considers sex work as "womanly work, like sewing and cooking, not manly work as his brothers did," he adopts varying gendered and sexual identifications throughout his romance with Yudi (201). His feeling of exultation, when Yudi fights for him at Testosterone, and participation in rangoli certainly interrogate the meaning of his own received understanding of conventional gender roles. The two instances above reinforce the queer paradigm of destabilizing the normative grid of gender and sexuality in the novel.

The novel also explores the inflections of class and caste in the Indian context within the wider framework of sexuality. Queer scholars have recently begun to address the absence of class and thirdworld/ethnic contexts from the larger queer paradigm. Thus, Terry Goldie in the special issue of Ariel on the intersection of postcolonial and queer studies contests, "the end of ethnicity as a social category" within recent cultural studies and critiques the relegation of the "social configuration of homosexuality" to a marginal element in queer studies (21). Likewise, critiquing the globalization/Americanization of queer identities, Donald Morton addresses the following question in his work on developing a materialist queer scholarship: "How must the 'global' be theorized so as to enable social justice worldwide to all?"(207). Developing the debate, Rob Cover questions the "assumption that worldwide sexual subjects transgressing heteronormativity operate in the same way" as, he adds, "it ignores the different inflections class and postcolonial ethnicity perform on the sexual subject" (31).

Any nuanced reading of Rao's novel, therefore, must engage with the questions of class and caste as these sites intersect with those of the sexual identities of Yudi and Milind. Yudi is a journalist and belongs to the English-speaking, educated upper strata of Indian society. He is always aware of this privilege and even uses it to his advantage in his sexual encounters. One such incident is his sexual encounter with Dyaneshwar, a local police officer. After having sex, Dyaneshwar extorts money from Yudi who in turn uses his class advantage and network of local gay queens in Testosterone to get Dyaneshwar roughed up (35-37), an incident he describes as the Operation Stonewall, equating it to the famous homosexual rebellion in New York. Without his class privilege, Yudi could certainly never imagine the act of publicly humiliating Dyaneshwar. 
As an English-speaking journalist, Yudi belongs to the upper classes. His class privilege affords him an unconventional life since he is unmarried at the age of forty-two, in contrast to Milind, who marries according to his parents' wishes. Yudi often speaks in English to the boys he takes home and is extremely suspicious of blackmail from his lovers, including Milind. He uses English as a tool to impress the lower-class boys he takes home and as a means of intimidating them in case of an eventual blackmail since English is the language of the elite and the economically privileged in India. As Aijaz Ahmad remarks, English is significant in India not because it is "simply one of India's languages now," but because it "is used in the processes of class formation and social privilege" (77). Its defining feature is, as Ahmad adds, "its differential availability to the propertied and the working classes respectively ... the greater access it provides to the job market and hence the great prestige that attaches to the person who commands it with fluency" (77). Yudi is conscious of this social prestige and reveals an anxiety at losing the privilege that English bestows upon him. When he goes to Gauri's house for her birthday, he makes sure that her father, the Colonel, does not label him "a Telugu-speaking country bumpkin" (65). At the inquisitive look on the Colonel's face at not understanding why Yudi would not speak Telugu, he quickly asserts, "I'm not that kind of Andhradu, from the depths of Samalkota, you know ... My mother is not a Telugu. We speak English at home" (65). Thus, Yudi consciously identifies with a position of privilege in which English and Telugu do not appear simply as two languages of postcolonial India but as markers of "the propertied and the working classes."

Even though he admits that he is guilty of class prejudice before meeting Milind, (and in Milind's company, he could say with "absolute conviction" that "people were no different from each other"), udi's bias resurfaces at the pilgrimage to Chaitya Bhoomi and at Milind's heterosexual wedding (105). He wonders why the Dalits are "unhygienic" (173). At the pilgrimage, he affirms his privilege of being upper-caste by comparing the Dalits to "our colonial masters" who are "used to bathing once a week" (173). He cannot understand why "almost all of them stank" (173). At Milind and Leela's wedding his essentialist understandings of class surpass largely his chagrin at lost love. Yudi's cross-class sympathies disappear once Milind is (re-)married. Rao critiques Yudi's class bias by making his prejudice reappear during the wedding ceremony. Yudi cannot relate to the aspirations of the Dalits, as they "were poor people, trying to look rich," and certainly, "the fakers had no idea what to apply to their rancid bodies" (219). In the festivities of their weddings, he would prefer to hear cheap Bollywood numbers rather than cultural 
masterpieces of Indian classical music. He thinks it is "an insult . . to Bismillah Khan" to be played at such weddings (219).

Yudi's understanding of his own homosexual identity is definitely inflected by his class privilege. He believes that "there was indeed something sensual about filth" (28). Besides, he never fully trusts Milind. When Milind loses his job as an office boy, he prefers to give him pocket money rather than have the boy live in his place, as he cannot bear the boy's gutkha (tobacco granules) eating habit, which leaves "red blotches all over his bathroom tiles" and which "nauseates him" (105). Similarly, immediately after their wedding they watch a Bollywood film in which the hero pushes the heroine off the terrace on the day of their wedding. Both Yudi and Milind think that "the bloody movie" might give the other "ideas" (109). Yudi even has a "theory based on years of experience" about which sexual role to offer the lower-class boys he takes home (12). He offers the active role to his partners because he believes, "as long as men were allowed to penetrate, there was no fear of their returning afterwards to demand money or beat you up" (12). Significantly, he does not mind "if his lovers thought of him as a hijra. It was so much more relaxing if one was freed of the need to perform" (12-13). The interaction of class and Yudi's sexual desire for lower classes is apparent in the choice of music he plays for his partners. He categorizes them into three classes: first, the English-speaking professionals, for whom "he usually played classical music"; second, the college students from Gujarati or Marathi backgrounds, for whom "Western pop music" was "compulsory"; and finally, the men from the working class for whom it was Hindi film music or music channels on television (26-27). For Yudi, this choice acts as an entrance into lower-class submission.

Milind can be termed the "queer subaltern" in the novel. Drawing upon subaltern scholarship, Ratna Kapur articulates the position of the "sexual subaltern" as "the complex layering of sexual subjectivities in a postcolonial context that are not captured in a straightforward 'lesbian' or 'gay' reading" (383). Given the persistence of non-normative gender and sexual identifications in the novel, I would suggest that the term "queer subaltern" (a slight variation of Kapur's formulation) appropriately incorporates Milind's class, sexual, caste and gender positions. Coming from an underprivileged class and caste background, like Yudi, Milind is conscious of the chasm between him and his lover. Despite Yudi's attraction for him, he undergoes a condescending process of othering at their first meeting. Yudi addresses him as the "boy," and is surprised that he does not know how to use a condom at the age of nineteen (9). Class anxiety restrains Yudi from letting Milind live in his house for more than a week. Milind is cautious enough to announce to Yudi that he is a Dalit, in case Yudi did not want to kiss an 
untouchable "whose ancestors cleaned the shit of others" (74). He is aware that Yudi can manage his gay lifestyle because he is a member of the upper echelons of society and that "for the middle class, indecent behaviour is a crime" (82).

As a Dalit, Milind has to negotiate not only his class status but his sexual preference as well, which compounds his marginality within Indian society. For him, Yudi belongs to the "talking class" who, as Debjani Ganguly points out, has "the prerogative of setting the terms that might enable (the) dalit lad to "speak correctly" (43). As he awaits Yudi in the lobby of the Taj hotel, he is manhandled and thrown out by the guard as "it is not a refuge for the city's urchins" (98). On their trip to Shravanabelagola, he feels compelled to please Yudi and follow him "like a sorry dog follows his master," as "at the end of the day, it was Yudi who held the purse strings" (128). For Gauri, he is not even a "respectable Dalit whom the government's reservation policy had transformed into, say, a college lecturer" (196). As Cover argues, if the "needs of survival are over-riding" as in the case of third-world sweatshops, then the body cannot be used for the purposes of desire (45). Similarly, Milind is at the margins of society and has to negotiate his existence before his sexual orientation.

Milind's self-perception of his sexual identity remains heteronormative, as he does not believe that playing the "active" role in bed makes him homosexual. The novel shows him as an example of internalized homophobia, whereby he does not wish to be labeled a chhakka, a homosexual (209). His sexuality is a reminder to the reader of how sexual acts differ from an individual's sexual identity. Within queer research, this notion signals the ongoing disruption of constructions of sexuality from the perspective of non-white and thirdworld cultural differences. In his detailed study of homosexuality in India, Shivananda Khan states that the insistence on sexual desire has informed much scholarship in lesbian and gay paradigms in the West. However, the validity of a discourse on sexuality and sexual identity is questioned in the South Asian context, where "clear distinctions between concepts of 'active' and 'passive,' concepts of 'discharge,' 'pleasure,' and 'desire' take precedence" (106). Surely, such concepts operate in Milind's construction of his sexuality, as for him sexual identity is not a primary marker of his subjectivity. The urban elite and members of the privileged class, like Yudi, however, do define their sexual identity as "gay" or "queer," and Khan points out that many such discourses crisscross with the former view. One such instance of this perception in the novel is Milind's surprise when Yudi makes him read same-sex matrimonial advertisements in the gay magazine, Bombay Dost (84). Similarly, when Yudi informs Milind that being gay is an integral part of his life, Milind fails to comprehend the meaning of 
Yudi's gay identity. Milind queries, "But you are a Brahman, aren't you?" Yudi simply retorts, "No I am a homosexual. Gay by caste. Gay by religion" (81). Milind's astonishment, in both the events, arises out of the different class spheres that Yudi and Milind inhabit. It demonstrates the opacity of these spheres in the postcolonial nation, whereby class and caste segregation manifests in the availability of the press.

Although Milind's perception of his gender identity is partially queered by the end of the novel and in Yudi's view he becomes the "tender gender bender," his sexuality remains defined in terms of the sexual act; he constantly perceives himself as the penetrator (108). As Khan asserts, "the act of sexual penetration is not so much a definer of identity, but one of phallic power" so that the penetrator retains his "manliness" (107). Thus, the survey in the A.K. modeling agency reveals that "most ... boys didn't think they were abnormal or perverted as long as they were "active"" (180). Certainly, for Milind, then, marriage and family are far stronger markers of identity than his "sexual acts." He may regret that his life would have been different had Yudi asked him to live with him years earlier. However, on returning from his night with Yudi (after he procured money for his family), he thinks with a note of contempt of "how he fucked him (Yudi) on the fancy bed on which his (Yudi's) mother once slept," and this thought remains foremost on his mind (230). Vanita suggests that the exploiter/exploited binary is often inverted in cross-class relations:

When the social superior is single and the subordinate married, heterosexual privilege may trump class privilege and result in a transaction that is mutually useful but that downgrades the gay person. This happens in R. Raj Rao's The Boyfriend (2003), where gay protagonist, Yudi, a journalist, manages to retain his relationship with his working class boyfriend Milind only by supporting him financially, while Milind, who gets married to a woman, despises Yudi for homosexual identity and single status. (Love's Rite 244)

Milind's contempt for Yudi, his class and his homosexuality cannot endorse the idea of a "perfect arrangement" as Yudi would like to believe at the end of the novel (232). Perhaps the most important feature of the novel is that this "perfect arrangement" appears unambiguously flawed by Milind's derision of Yudi. By extension, the feeling of disdain that Milind reserves for Yudi through the last portions of the narrative appears as the dominant characteristic of their romantic union. This emotion further defines the state of a cross-caste and cross-class union that Yudi imagines. By conjoining negative aspects to Yudi and Milind's affection, Rao critiques the larger context of Dalit/non-Dalit and upper/lower class relations, which can only partially resist longstanding histories of segregation. 
This paper has affirmed how questions of nation and queerness are inter-implicated and how a queer inquiry exposes the fractures of a postcolonial nation. The policing of homosexualities in postcolonial India and their subsequent marginalization in mainstream discourse reveals a discomfort at addressing the problematic of sexual desire itself. Rao's novel deconstructs received understandings of sexuality, sex and gender in India and inscribes the queer subculture of Bombay as a legitimate part of Indian culture, thus counterbalancing homophobic nationalist discourses that reproduce normative sexualities. Read in conjunction with one another, the queer union of Yudi and Milind against the backdrop of Milind's heterosexual marriage to Leela, the recasting of Hindu myths, the presence of hijras and the use of a homo-specific language in the gay subculture of Bombay, gesture toward critical resistance to heteronormative discourses of postcolonial India. In this regard, The Boyfriend negotiates a space for queer representation within the context of Indian/Hindu nationalism and appears as a counter-narrative (in the Foucauldian sense of the term) to the "conspiracy of silence" concerning homosexuality in India. Although Milind's contempt for Yudi and the conflicting class/caste impediments to same-sex love reposition the queer narrative of resistance to the heteronormative nation as "fractured resistance," Rao's text queerly extends the literary archive in order to redefine the representational norm of what constitutes Indian culture.

\section{Notes}

1. I borrow from Jasbir Puar's coinage of the term "homonationalism," which arises from a process of "inclusion and exclusion" to create an effect of "homonormative nationalism" (9). Bhardwaj's idea of the "ultimate vision of India" points to such a process of inclusion within the nation.

2. Rao is the author of another work of gay romance titled Hostel Room 131 (2010). He is an active member of the nascent queer movement in Pune (India) where he resides and teaches. Besides fiction, he has published anthologies of poetry and critical essays.

3. Paola Bacchetta rightly considers this trait of Hindu nationalism as a manifestation of "dual operations of xenophobic queerphobia and queerphobic xenophobia" in which Islam functions as an outsider (143).

4. For an insightful explanation of the homoerotic bond between the two Hindu sages, see Vanita and Kidwai, 230.

5. For a detailed definition of hijras, see Bakshi 212-14. The term "cisgender" implies a normative gendered identity whereby the enactment of an individual's gender conforms to the biological sex assigned to them at birth.

\section{Works Cited}


Ahmad, Aijaz. In Theory: Classes, Nations, Literatures. London: Verso, 1992. Print.

Bacchetta, Paola. "When the (Hindu) Nation Exiles its Queers." Social Text 61 (1999): 141-66. JSTOR. Web. 20 Jan. 2011.

Bakshi, Sandeep. "A Comparative Analysis of Hijras and Drag Queens: The Subversive Possibilities and Limits of Parading Effeminacy and Negotiating Masculinity.” Journal of Homosexuality 46.3 (2004): 211-23. Print.

Bhabha, Homi. The Location of Culture. London: Routledge, 1994. Print.

Bhan, Gautam. "Challenging the Limits of Law: Queer Politics and Legal Reform in India." Because I Have a Voice: Queer Politics in India. Ed. Arvind Narrain and Gautam Bhan. New Delhi: Yoda P, 2005. 40-48. Print.

Bhardwaj, Kajal. "Reforming Macaulay." Narrain and Elridge 97-100. Print.

Butler, Judith. Gender Trouble: Feminism and the Subversion of Identity. New York: Routledge, 1990. Print.

- "Imitation and Gender Insubordination." The Lesbian and Gay Studies Reader. Ed. Abelove, et al. New York: Routledge, 1992. 307-20. Print.

Cover, Rob. "Queer with Class: Absence of the Third World Sweatshop in Lesbian/Gay Discourse and a Rearticulation of Materialist Queer Theory." Ariel 30.2 (1999): 29-48. Print.

Ganguly, Debjani. "Can the Dalit Speak: Caste, Postcoloniality and the New Humanities?" South Asia 23.1 (2000): 43-62. Print.

"Gay Ruling: 'Now we're really in the $21^{\text {st }}$ Century."' The Times of India. 3 July 2009. Web. 8 Sept. 2010.

Chari, Hema. "Colonial Fantasies and Postcolonial Identities: Elaboration of Postcolonial Masculinity and Homoerotic Desire." Postcolonial, Queer: Theoretical Intersections. Ed. John Hawley. Albany: SUNY P, 2001. 277304. Print.

Goldie, Terry, ed. Introduction. Queerly Postcolonial. Spec. issue of Ariel 30.2 (1999): 9-26. OJS. Web. 26 Feb 2011.

Hall, Kira. "Go Suck your Husband's Sugarcane: Hijras and the Use of Sexual Insult." Queerly Phrased: Language, Gender, and Sexuality. Ed. Anna Livia and Kira Hall. New York: OUP, 1997. 430-60. Print.

John, Mary E., and Janaki Nair. A Question of Silence: An Introduction. $A$ Question of Silence: The Sexual Economies of Modern India. By John and Nair. Delhi: Kali for Women, 1998. Print.

Kapur, Manju. A Married Woman. London: Faber and Faber, 2003. Print.

Kapur, Ratna. "Out of the Colonial Closet, but still thinking 'Inside the Box': Regulating 'Perversion' and the Role of Tolerance in Deradicalising the Rights Claims of Sexual Subalterns." NUJS Law Review 381 (2009): 38196. JSTOR. Web. 21 Dec. 2010.

Khan, Shivananda. "Culture, Sexualities, and Identities: Men who have Sex with Men in India.” Journal of Homosexuality 40.3-4 (2001): 99-115. Print.

Morton, Donald. "Global (Sexual) Politics, Class Struggle, and the Queer Left.” Postcolonial, Queer: Theoretical Intersections. Ed. John Hawley. Albany: SUNY P, 2001. 207-38. Print.

Narrain, Arvind. "Rethinking Citizenship: A Queer Journey." Indian Journal of Gender Studies 14.1 (2007): 61-71. Print. 
—, and Marcus Elridge, eds. The Right that Dares to Speak its Name: Decriminalising Sexual Orientation and Gender Identity in India. Bangalore: Alternative Law Forum, 2009. Print.

Puar, Jasbir K. Terrorist Assemblages: Homonationalism in Queer Times. Durham: Duke UP, 2007. Print.

Puri, Jyoti. Encountering Nationalism. Maiden, MA: Blackwell, 2004. Print.

Rao, R. Raj. The Boyfriend. New Delhi: Penguin, 2003. Print.

Shahani, Parmesh. Gay Bombay: Globalization, Love and (Be)Longing in Contemporary India. New Delhi: Sage, 2008. Print.

Tellis, Ashley. "Why I Can't Join the Party." The Hindu. 12 July 2009. Web. 1 Oct. 2009.

Vanita, Ruth. Love's Rite: Same-Sex Marriage in India and the West. New Delhi: Penguin, 2005. Print.

-, ed. Queering India: Same-Sex Love and Eroticism in Indian Culture and Society. New York: Routledge, 2002. Print.

-, and Saleem Kidwai, eds. Same-Sex Love in India: Readings from Literature and History. New York: Palgrave, 2001. Print. 